\title{
Comparative Efficacy of Rock Phosphate Enriched Organic Fertilizer vs. Mineral Phosphatic Fertilizer for Nodulation, Growth and Yield of Lentil
}

\author{
Allah Ditta ${ }^{1^{*}}$, Muhammad Arshad ${ }^{1^{*}}$, Zahir A. Zahir ${ }^{1}$ and Amer Jamil ${ }^{2}$ \\ ${ }^{1}$ Institute of Soil and Environmental Sciences, University of Agriculture Faisalabad 38040, Pakistan \\ ${ }^{2}$ Department of Chemistry and Biochemistry, University of Agriculture Faisalabad 38040, Pakistan \\ *For correspondence: arshad_ises@yahoo.com; ad_abs@yahoo.com
}

\begin{abstract}
Optimum impregnation ratio of rock phosphate (RP) and compost in RP-enriched organic fertilizer, its time and rate of application to the crop plants affect the availability of nutrients through the process of mineralization and immobilization. A series of pot and field experiments were conducted to investigate the comparative efficacy of RP-enriched organic fertilizer vs. mineral phosphatic fertilizer on growth, yield and nodulation of lentil. Optimum impregnation ratio of RP and compost and the time of application to improve growth, nodulation and yield of lentil were investigated under wire house conditions. The impregnation ratio of 50:50 RP and compost and time of application of seven days before sowing resulted in the maximum nodulation, growth and yield parameters compared to the other impregnation ratios and the times of application. Optimized impregnation ratio and time of application were further investigated for optimum rate of application under field conditions to enhance nodulation, growth and yield of lentil in comparison with recommended mineral phosphatic fertilizer. The application of RP-enriched organic fertilizer @ $1000 \mathrm{~kg} \mathrm{ha}^{-1}$ showed an increase of 35.5, 27 and 6\% in number of nodules, fresh weight of nodules, and grain yield compared to chemical phosphatic fertilizer, respectively. Similarly, significant increase in P contents of straw and grain was also observed with the application of RP-enriched organic fertilizer @ $1000 \mathrm{~kg} \mathrm{ha}^{-1}$ compared to chemical phosphatic fertilizer. However, the effect of the application of 800 and $1000 \mathrm{~kg} \mathrm{ha}^{-1}$ was statistically non-significant for most of the parameters studied. The results suggested that RP-enriched organic fertilizer with optimum impregnation ratio of RP and compost, time of application and rate of application had a pronounced effect on nodulation, growth and yield of lentil as compared to recommended chemical phosphatic fertilizer. (C) 2015 Friends Science Publishers
\end{abstract}

Keywords: Phosphorus; Impregnation ratio; Rock phosphate; Time of application; Rate of application; Mineral phosphatic fertilizers; Lentil

\section{Introduction}

The organic waste recycling as organic fertilizer for the maintenance of soil health through hygienic methods is vital for sustainable crop production and the welfare of mankind. Addition of organic fertilizer to the soil in the form of compost, farm yard manure, green manure and cereal residues has been well known for improving the physicochemical and biological properties of the soil. It has not only served as source of macro and micro-nutrients for the crop plants but also for the microbes in supporting soil health by serving a quick and easily available source of carbon (Darzi et al., 2012). Energy has been a key limiting factor in getting the maximum crop yields per unit area per unit time. The major advancement in agriculture has been brought about by the use of non-renewable energy sources, the cost of which has risen sharply during the last 2-3 decades and ultimately has increased the prices of chemical phosphatic fertilizers (Meena and Biswas, 2014).
The burning of rural and urban refuse without energy recuperation or their use for land filling are wasteful processes, which should be avoided. On the other hand, composting is a microbiological process for the conversion of organic wastes into a valuable product. It also helps in the reduction of environmental pollution. Moreover, the refuse dumping sites on the outskirts of cities are gradually decreasing due to their massive expansion. Traditional methods of composting have proven unsuitable for the disposal of huge quantities of city wastes. The value of compost not only lies in its macro- and micronutrients but also in its humus contents, which ultimately help in the restoration of soil fertility through the maintenance of organic matter. Addition of organic matter will ultimately help in the restoration of soil fertility (Diaz et al., 1993).

Phosphorus $(\mathrm{P})$ is the second most limiting nutrient element after nitrogen under most of the soil conditions worldwide (Vance et al., 2003). Its availability to the crop plants through the application of chemical phosphatic 
fertilizers is not more than $20 \%$. The situation becomes more adverse in case of leguminous crops, which require more phosphorus compared to the other crops. This has led to the application of phosphatic fertilizers in large amounts than the recommended one and has increased the cost of crop production (Aziz et al., 2006). On the other hand, their application has decreased due to the sky-high prices, scarcity at the right time of application and sub-optimal doses so it has become a burden for the farmers especially living in the developing countries. Another constraint with chemical phosphatic fertilizers is that these are prepared from high quality RP which may be depleted by the year 2050 (Vance et al., 2003). Need of the hour is to find out certain other approaches in order to exploit indigenous rock phosphate resources in bioavailable form without compromising yield.

Rock phosphate is a raw material in the manufacture of chemical phosphatic fertilizers and during the last decade, has been recognized as an important alternative economical source of P for the crops (Reddy et al., 2002). There are many reports about the direct application of RP as a $\mathrm{P}$ source to the soils (Chien and Menon, 1995; Akande et al., 2008; Iqbal et al., 2013). From these studies, it has been clearly found that this approach is feasible for the acidic soils having low $\mathrm{pH}$ and direct application of RP to the alkaline/calcareous soils as prevailing in Pakistan is not a feasible approach (Caravaca et al., 2004).

There are certain plant growth promoting rhizobacteria (PGPR), which have both 1-aminocyclopropane-1carboxylate (ACC)-deaminase and P-solubilizing activities. The former reduces the production of stress hormone, the ethylene, by converting its intermediate biosynthesis components into $\alpha$-ketobutyrate and ammonia (Glick et al., 1998) and the latter increases the availability of fixed $P$ from the RP through the production of organic acids. Higher concentrations $\left(25 \mu \mathrm{g} \mathrm{L}^{-1}\right)$ of ethylene have been reported to inhibit root growth (Mattoo and Suttle, 1991) and nodulation (Arshad and Frankenberger Jr., 2002). Stimulatory effect on the plant growth of maize and mungbean was reported with the application of bacteria carrying ACC-deaminase activity (Shaharoona et al., 2006). The application of PGPR helps increase the root proliferation, which provides greater surface area to explore more volume of the soils for better uptake of the fixed P (Dey et al., 2004). Microorganisms are involved in a range of processes that affect the transformation of soil $\mathrm{P}$ during soil P cycle (Chen et al., 2006). It would be imperative to use the microbes with ACC-deaminase as well as Psolubilizing activity for decreasing the stress hormone, the ethylene, produced during the infection process of nodulation and increasing the availability of $\mathrm{P}$ from RP.

Very recently, interest has been renewed in the compost technology. A wise manipulation of the composted material could be to enrich it with RP and PSM, which ultimately reduce its application amount; a laborious part of the process. During composting, most of the organic $\mathrm{P}$ in the organic form is converted into inorganic form through mineralization, which ultimately increases the availability of P to the crop plants (Condron et al., 2004). At the same time, certain acids are released during composting which also increase the release of plant available-P from RP. Use of microbial inoculants along with RP-enriched organic fertilizer to prevail over the ecological problems resulting from the loss of plant nutrients and enhancing nutrient use efficiency/nutrient availability could provide sustainable solution for agriculture system. Reports are available on the combined use of RP along with compost and PSM (Saleem et al., 2013; Shahzad et al., 2014); however, no work has been conducted to find out the optimum impregnation ratio of RP and compost, its time and rate of application for the maximum production of crop plants. Keeping in view the above discussion, a series of studies were planned to determine (a) whether or not RP-enriched organic fertilizer is as effective as mineral fertilizer; (b) the optimum impregnation ratio of RP and compost, time and rate of application of RP-enriched organic fertilizer to enhance nodulation, growth and yield of lentil under wire house and field conditions.

\section{Materials and Methods}

\section{Preliminary}

A series of pot and field experiments were conducted to investigate the optimum impregnation ratio of RP and compost, and the optimum time of application to improve nodulation, growth and yield of lentil. A pre-isolated strain i.e. Bacillus spp. strain PSM (previously reported as KAP6) was used in the study. The strain (PSM) had high Psolubilizing $\left(753.0 \mu \mathrm{g} \mathrm{mL}^{-1}\right)$ and high ACC-deaminase

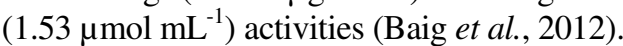

\section{Preparation of RP-enriched Organic Fertilizer}

Composting materials consisting of fruit peels and vegetable wastes were collected from the local market of Faisalabad city (longitude $72^{\circ} 0^{\prime}$ and $73^{\circ} 45^{\prime}$ East and $30^{\circ} 30^{\prime}$ and $32^{\circ} 0^{\prime}$ North), Pakistan, oven dried $\left(70^{\circ} \mathrm{C}\right)$ for $24 \mathrm{~h}$ and ground to fine powder $(<2.0 \mathrm{~mm})$ with the help of electric grinder. The crushed materials were mixed with RP in ratios of 0:100, 25:75, 50:50, 75:25 and 100:0, respectively subjected to composting process in a locally fabricated composter (500 kg capacity) and were continuously run for seven days. Each RP-enriched organic fertilizer with specific ratio was prepared separately after thoroughly removing the first one. The moisture contents were maintained manually $(40 \%$ $\mathrm{v} / \mathrm{w})$. Temperature rose up from 30 to $70^{\circ} \mathrm{C}$ in the composting unit during $2^{\text {nd }}$ and $3^{\text {rd }}$ day of composting process and then reduced gradually to $30^{\circ} \mathrm{C}$ after $4^{\text {th }}$ day process. After 7 days, the RP-enriched organic fertilizer produced was subjected to analysis regarding various macronutrients and $\mathrm{C} / \mathrm{N}$ and $\mathrm{C} / \mathrm{P}$ ratios were determined. 
Similarly, simple compost was also prepared from the crushed materials of fruit peels and vegetable wastes.

\section{Compost and RP-enriched Organic Fertilizer Analysis}

The chemical analysis of compost and RP-enriched organic fertilizer before and after the composting was done by using standard methods (Table 1). Carbon content of RP-enriched organic fertilizer was estimated by loss-on-ignition method (Nelson and Sommers, 1999; Ryan et al., 2001). Total nitrogen $(\mathrm{N})$ content was determined by using Kjeldahl distillation apparatus (Jackson, 1962). For phosphorus (P) determination, $1.0 \mathrm{~g}$ dried and ground RP-enriched organic fertilizer sample was taken and digested by adding $25 \mathrm{~mL}$ of conc. $\mathrm{HNO}_{3}$ followed by $20 \mathrm{~mL}$ of $60 \% \mathrm{HClO}_{4}$. After digestion, vanadomolybdo-phosphoric yellow color complex in nitric acid medium was added to the samples and placed for 10 minutes until the color was developed (Jackson, 1973). Then the total P content was determined by taking the reading of absorbance using spectrophotometer (Beckman photometer 1211, London). Moreover, C:P and $\mathrm{C}: \mathrm{N}$ ratios were also calculated.

\section{Pot Experiments}

A pot experiment was conducted to find out the optimum impregnation ratio of RP and compost in RP-enriched organic fertilizer $(0: 100,25: 75,50: 50,75: 25$ and 100:0) to enhance nodulation, growth and yield of lentil under wire house conditions. The trial was conducted in the research area of the Institute of Soil and Environmental Sciences, University of Agriculture, Faisalabad, Pakistan, using completely randomized design (CRD) with six replications. The inoculum of selected strain was prepared by growing in $250 \mathrm{~mL}$ Erlenmeyer flask containing National Botanical Research Institute's Phosphate (NBRIP) medium [Glucose, $10.0 \mathrm{~g}: \mathrm{Ca}_{3}\left(\mathrm{PO}_{4}\right)_{2}, 5.0 \mathrm{~g} ; \mathrm{MgCl}_{2} \cdot 6 \mathrm{H}_{2} \mathrm{O}, 5.0 \mathrm{~g} ; \mathrm{MgSO}_{4} \cdot 7 \mathrm{H}_{2} \mathrm{O}$, $0.25 \mathrm{~g} ; \mathrm{KCl}, 0.2 \mathrm{~g}$ and $\left(\mathrm{NH}_{4}\right)_{2} \mathrm{SO}_{4}, 0.1 \mathrm{~g} \mathrm{~L}^{-1}$ ] (Nautiyal, 1999) for PSM. The flasks were incubated at $28 \pm 1^{\circ} \mathrm{C}$ for 48 $\mathrm{h}$ in the orbital shaking incubator (Model OSI-503 LD; Firstek Scientific, Japan) at $180 \mathrm{rev} \mathrm{min}^{-1}$. Rhizobia specific to lentil were kindly provided by the Microbiology Section at Ayub Agricultural Research Institute (AARI), Faisalabad. Lentil seeds were surface sterilized by dipping in $70 \%$ ethanol for $2 \mathrm{~min}$ and treated with $5 \% \mathrm{NaClO}$ for $5 \mathrm{~min}$ followed by washing 3 times with sterile distilled water. For inoculation, surface sterilized seeds of lentil were coated with suspension of the strain, $15 \%$ sugar solution and peat plus clay $(1: 1 \mathrm{w} / \mathrm{w})$. Control was treated with sterilized peat plus clay containing sterilized broth and sugar solution. Inoculated seeds were placed under shade for drying. For pot experiment, sandy clay loam soil (surface layer 0-15 $\mathrm{cm}$ ) passed through a $2 \mathrm{~mm}$ sieve (40 mesh) was used for filling the pots. Pre-soil analysis regarding physic-chemical properties was done using standard methods described in Hand Book 60 (US Salinity Laboratory Staff, 1954). The soil used in the study was sandy clay loam having $\mathrm{pH}, 7.6$;
ECe, $3.4 \mathrm{dS} \mathrm{m}^{-1}$; organic matter, $0.67 \%$; total $\mathrm{N}, 0.056 \%$ and available $\mathrm{P}, 8.6 \mathrm{mg} \mathrm{kg}^{-1}$. Each pot was filled with $12 \mathrm{~kg}$ soil receiving nutrients $P$ and $K$ at the rate of 50 and $25 \mathrm{~kg}$ $\mathrm{ha}^{-1}$ as single super phosphate and sulphate of potash, respectively. The whole amount of $\mathrm{P}$ and $\mathrm{K}$ were applied by mixing them uniformly with soil before filling the pots. Four seeds of chickpea were sown in each pot at soil moisture level (water holding capacity) of $70 \%$. One seedling was retained in each pot after germination. For nodulation parameters, three replicates from each treatment (originally six) were harvested at the flowering stage, nodules were excised manually and their fresh and dry weight was recorded using electrical balance. At maturity, agronomic and yield contributing parameters were measured using standard procedures. Grain and straw samples were analyzed for $\mathrm{N}$ and $\mathrm{P}$ using standard methods of Jackson (1962) and Ryan et al. (2001), respectively.

In the second pot experiment, optimum time of application of RP-enriched organic fertilizer (30, 15, 7, 3 and 0 days before sowing) with optimized impregnation ratio of $\mathrm{RP}$ and compost i.e. 50:50 was investigated to enhance nodulation, growth and yield of lentil. The trial was conducted under similar environmental condition as stated above. For inoculum preparation and its application methods were the same as described in the above pot experiment. Similar procedures were adopted to quantify the growth, nodulation and yield parameters.

\section{Field Experiment}

A field experiment was conducted to evaluate the effectiveness of different application rates (100, 200, 300, 400, 500, 800 and $1000 \mathrm{~kg} \mathrm{ha}^{-1}$ ) of RP-enriched organic fertilizer with optimized impregnation ratio of RP and compost (50:50) and time of application (7 days before sowing) to improve nodulation, growth and yield of lentil as compared to recommended chemical phosphatic fertilizer (60 $\left.\mathrm{kg} \mathrm{P} \mathrm{ha}{ }^{-1}\right)$. The experiment was conducted in the research area of the Institute of Soil and Environmental Sciences, University of Agriculture, Faisalabad, Pakistan, using randomized complete block design (RCBD) with six replications. The recommended rate of $\mathrm{N}\left(25 \mathrm{~kg} \mathrm{ha}^{-1}\right)$ and rhizobia were applied in all treatments. For inoculum preparation and its application to the seeds was followed by the methods described earlier. At flowering stage, nodulation parameters were recorded by uprooting ten plants randomly from each replicate plot. Similarly, to quantify the growth and yield parameters at maturity, the whole plot replicate of each treatment was harvested.

\section{Statistical Analysis}

The data were subjected to analysis of variance technique (ANOVA) using Statistix v. 8.1 software package (Analytical Software, 2005). The means were compared by least significant difference (LSD) test (Steel et al., 1997). 


\section{Results}

\section{Nodulation Parameters}

The results clearly showed that the impregnation ratio 50:50 of RP and compost and the application time of seven days before sowing significantly increased the number of nodules plant $^{-1}$, fresh and dry weight of nodules of lentil as compared to the other impregnation ratios and the times of application (Table 2 and 3). The maximum number of nodules plant ${ }^{-1}$ was recorded with the application of 50:50 impregnation ratio of RP and compost (36 number of nodules plant ${ }^{-1}$ ) and with the application time of seven days before sowing ( 35 number of nodules plant ${ }^{-1}$ ) while that of the minimum was recorded with the impregnation ratio of 0:100 RP and compost (17 number of nodules plant ${ }^{-1}$ ) and with the application time of 30 days before sowing (16 number of nodules plant $\left.{ }^{-1}\right)$. Similar trend in case of fresh and dry weight of nodules ( $\mathrm{g}$ ) was observed. In case of field experiment, the maximum number of nodules plant ${ }^{-1}$ was recorded with the application of RP-enriched organic fertilizer@1000 kg ha ${ }^{-1}$ which was 35.5\% more as compared to control (Table 4). The minimum number of nodules plant ${ }^{-1}$ was observed with the application of RPenriched organic fertilizer @ $100 \mathrm{~kg} \mathrm{ha}^{-1}$. Similar trend was observed in case of fresh and dry weight of nodules (g) over control. Data in Table 4 revealed a statistically nonsignificant effect between the application rate 800 and 1000 $\mathrm{kg} \mathrm{ha}^{-1}$ regarding nodulation parameters.

\section{Yield Parameters}

Growth and yield were significantly improved under different impregnation ratios of RP and compost and under different time of application (Table 2 and 3). The maximum grain yield was recorded with the application of impregnation ratio of 50:50 RP and compost (4.08 $\mathrm{g} \mathrm{pot}^{-1}$ grain yield) and with the application time of seven days before sowing (4.24 $\mathrm{g} \mathrm{pot}^{-1}$ grain yield). Similarly, the minimum grain yield was recorded with the application of impregnation ratio of $0: 100 \mathrm{RP}$ and compost $\left(0.85 \mathrm{~g} \mathrm{pot}^{-1}\right.$ grain yield) and with the application time of 0 days before sowing (1.00 g pot ${ }^{-1}$ grain yield). Similar trend was observed in total biomass. Under field conditions, the maximum grain yield was recorded with the application of RP-enriched compost @ $1000 \mathrm{~kg} \mathrm{ha}^{-1}$ which was 6\% more as compared to the control (Table 4). A maximum biological yield (4.74 $M g \mathrm{ha}^{-1}$ ) was recorded with the application of RP-enriched organic fertilizer @ $1000 \mathrm{~kg} \mathrm{ha}^{-1}$. The effect of the application rate of RP-enriched organic fertilizer @ 1000 and $800 \mathrm{~kg} \mathrm{ha}^{-1}$ was statistically non-significant regarding most of the growth and yield parameters recorded.

\section{P Content}

Data showed that $\mathrm{P}$ concentration in straw and grain that the applications of RP-enriched organic fertilizer with impregnation ratio of 50:50 RP and compost and with the application time of seven days before sowing significantly increased the nitrogen content of straw and grain (Table 2 and 3). The maximum P content in straw was recorded with the application RP-enriched organic fertilizer with impregnation ratio of 50:50 RP and compost $(0.28 \% \mathrm{P})$ and with the application time of seven days before sowing $(0.31 \% \mathrm{P})$ as compared to other impregnation ratios and the application time. Similar trend was observed in case of the $\mathrm{P}$ contents of grains as found in case of $\mathrm{P}$ contents in straw. Under field conditions, maximum $\mathrm{P}$ content in straw $(0.26 \%)$ was recorded with the application of RP-enriched organic fertilizer@1000 kg ha ${ }^{-1}$ and in case of control $(0.26 \%)$ set (Fig. 1). Similarly, the maximum P contents in grain as recorded with the application of RP-enriched organic fertilizer @ $1000 \mathrm{~kg} \mathrm{ha}^{-1}$ which was $12.19 \%$ more as compared to the recommended NPK control.

\section{Discussion}

In the earlier studies, it has been suggested that the availability of P from low-grade RP could be increased by the combined application of RP and compost (Biswas and Narayanasamy, 2006; Verma et al., 2013). An increase in the P contents of RP-enriched organic fertilizer might be due to the production of organic acids by the microbes and their enzyme activities during the process of composting which decreased the $\mathrm{pH}$ of the material being composted and resulted in an increased release of fixed P from RP (Rashid et al., 2004). Previously, it has been reported that extracellular products of the microbial community such as enzymes and chelating agents (organic acids) have substantial effect on the mineralization of organic $\mathrm{P}$ present in the compost (Jansson et al., 1988). According to Chien (1979), a lot of $\mathrm{CO}_{2}$ is produced during composting which after combining with water forms carbonic acids and also helps in the reduction of $\mathrm{pH}$ of the materials being composted. This decreased $\mathrm{pH}$ would ultimately help solubilize the fixed $\mathrm{P}$ in the form of RP or in the soil (Bangar et al., 1989).

Growth and yield parameters were significantly improved, which implied that optimum impregnation ratio and time of application helped in better mineralization of nutrients present in the RP-enriched organic fertilizer, thereby increasing their availability to the crop plants and ultimately improved crop growth and yield. The effect of optimum impregnation ratio and the time of application were enhanced with the application of microbial strain, which possessed high P-solubilizing and ACC-deaminase activities. The ACC-deaminase activity of the PSM used ultimately reduced the ethylene stress and resulted in better root growth, which ultimately helped the plants to explore more soil and to get more nutrients (Shaharoona et al., 2006; Yang et al., 2009; Shahzad et al., 2014). 
Phosphorus Nutrition in Legumes through RP-enriched Organic Fertilizer / Int. J. Agric. Biol., Vol. 17, No. 3, 2015

Table 1: The chemical analysis of the compost and rock phosphate enriched compost (RP-EC)

\begin{tabular}{|c|c|c|c|c|c|c|}
\hline \multirow[t]{3}{*}{ Parameters } & \multirow{3}{*}{$\begin{array}{l}\text { Before composting } \\
\text { Raw organic material }\end{array}$} & \multicolumn{5}{|c|}{ After composting } \\
\hline & & \multicolumn{5}{|c|}{ Impregnation ratios of RP and compost, respectively } \\
\hline & & $0: 100$ & $25: 75$ & $50: 50$ & $75: 25$ & 100:0 \\
\hline Carbon $(\%)$ & 34.5 & 25.5 & 23.7 & 21.5 & 17.4 & - \\
\hline Nitrogen $(\%)$ & 1.38 & 2.21 & 1.71 & 1.53 & 1.24 & - \\
\hline Phosphorus (\%) & 0.34 & 0.45 & 2.07 & 2.38 & 2.15 & 2.17 \\
\hline $\mathrm{C}: \mathrm{N}$ & 25 & 11.53 & 13.85 & 14.05 & 14.03 & - \\
\hline $\mathrm{C}: \mathrm{P}$ & 101.47 & 56.67 & 11.45 & 9.03 & 8.09 & - \\
\hline
\end{tabular}

Table 2: Impact of the application of different impregnation ratios RP and compost in RP-enriched organic fertilizer on no. of nodules plant ${ }^{-1}$, fresh and dry wt. of nodules $(\mathrm{g})$, grain yield $\left(\mathrm{g} \mathrm{pot}^{-1}\right)$, fresh biomass $\left(\mathrm{g} \mathrm{pot}^{-1}\right), \mathrm{P}$ contents in straw and grains $(\%)$ of lentil

\begin{tabular}{|c|c|c|c|c|c|c|c|}
\hline $\begin{array}{l}\text { Impregnation ratio } \\
\mathrm{RP} \text { and compost }\end{array}$ & $\begin{array}{l}\text { of No. of } \\
\text { plant }^{-1}\end{array}$ & $\begin{array}{r}\text { nodules Fresh wt. } \\
\text { nodules }(\mathrm{g})\end{array}$ & $\begin{array}{l}\text { of Dry wt. of nodules } \\
(\mathrm{g})\end{array}$ & $\begin{array}{l}\text { Grain yield } \\
\left(\mathrm{g} \mathrm{pot}^{-1}\right)\end{array}$ & $\begin{array}{l}\text { Fresh biomass } \\
\left(\mathrm{g} \mathrm{pot}^{-1}\right)\end{array}$ & $\mathrm{P}$ in straw $(\%)$ & $\mathrm{P}$ in grain $(\%)$ \\
\hline $0: 100 \dagger$ & $17 b^{*}$ & $1.47 \mathrm{~b}$ & $0.32 \mathrm{~b}$ & $0.85 \mathrm{~d}$ & $10.4 \mathrm{ab}$ & $0.13 \mathrm{ab}$ & $0.22 \mathrm{~b}$ \\
\hline $25: 75$ & $27 \mathrm{ab}$ & $1.63 \mathrm{~b}$ & $0.47 \mathrm{a}$ & $1.63 \mathrm{c}$ & $11.6 \mathrm{ab}$ & $0.14 \mathrm{ab}$ & $0.26 \mathrm{ab}$ \\
\hline $50: 50$ & $36 \mathrm{a}$ & $2.04 \mathrm{a}$ & $0.55 \mathrm{a}$ & $4.08 \mathrm{a}$ & $12.4 \mathrm{a}$ & $0.22 \mathrm{a}$ & $0.33 \mathrm{a}$ \\
\hline $75: 25$ & $27 \mathrm{ab}$ & $1.40 \mathrm{~b}$ & $0.34 \mathrm{~b}$ & $2.31 \mathrm{~b}$ & $10.0 \mathrm{~b}$ & $0.13 \mathrm{ab}$ & $0.29 \mathrm{ab}$ \\
\hline 100:0 & $19 \mathrm{~b}$ & $1.06 \mathrm{c}$ & $0.26 \mathrm{~b}$ & $0.87 \mathrm{~d}$ & $6.8 \mathrm{c}$ & $0.10 \mathrm{~b}$ & $0.23 \mathrm{~b}$ \\
\hline
\end{tabular}

* Means followed by the same letters are not statistically different at $P<0.05$ according to least significance difference (LSD) test

$\dagger$ Impregnation ratio

Table 3: Impact of time of application of the optimum ratio of rock phosphate impregnation on no. of nodules plant ${ }^{-1}$, fresh and dry wt. of nodules $(\mathrm{g})$, grain yield $\left(\mathrm{g} \mathrm{pot}^{-1}\right)$, fresh biomass $\left(\mathrm{g} \mathrm{pot}^{-1}\right), \mathrm{P}$ contents in straw and grains $(\%)$ of lentil

\begin{tabular}{|c|c|c|c|c|c|c|c|}
\hline $\begin{array}{l}\text { Time } \\
\text { application }\end{array}$ & $\begin{array}{l}\text { of No. of } \\
\text { plant }^{-1}\end{array}$ & $\begin{array}{c}\text { nodules Fresh wt. } \\
\text { nodules }(\mathrm{g})\end{array}$ & $\begin{array}{l}\text { of Dry wt } \\
(\mathrm{g})\end{array}$ & $\begin{array}{l}\text { Grain yield } \\
\left(\mathrm{g} \mathrm{pot}^{-1}\right)\end{array}$ & $\begin{array}{l}\text { Fresh biomass } \\
\left(\mathrm{g} \mathrm{pot}^{-1}\right)\end{array}$ & $\mathrm{P}$ in straw $(\%)$ & $\mathrm{P}$ in grain $(\%)$ \\
\hline $30 \dagger$ & $16 \mathrm{c}^{*}$ & $1.74 \mathrm{~b}$ & $0.31 \mathrm{~d}$ & $1.04 \mathrm{~d}$ & $10.6 \mathrm{~b}$ & $0.16 \mathrm{ab}$ & $0.25 \mathrm{~b}$ \\
\hline 15 & $26 \mathrm{~b}$ & $1.83 \mathrm{~b}$ & $0.44 \mathrm{~b}$ & $1.80 \mathrm{c}$ & $11.8 \mathrm{a}$ & $0.16 \mathrm{ab}$ & $0.28 \mathrm{ab}$ \\
\hline 3 & $26 \mathrm{~b}$ & $1.67 \mathrm{~b}$ & $0.36 \mathrm{c}$ & $2.52 \mathrm{~b}$ & $10.3 \mathrm{~b}$ & $0.16 \mathrm{ab}$ & $0.32 \mathrm{a}$ \\
\hline 0 & $18 \mathrm{c}$ & $1.20 \mathrm{c}$ & $0.28 \mathrm{~d}$ & $1.00 \mathrm{~d}$ & $6.9 \mathrm{c}$ & $0.12 \mathrm{~b}$ & $0.25 \mathrm{~b}$ \\
\hline
\end{tabular}

$*$ Means followed by the same letters are not statistically different at $P<0.05$ according to least significance difference (LSD) test

$\dagger$ Days before sowing

Table 4: Impact of different application rates of RP-enriched organic fertilizer on no. of nodules plant ${ }^{-1}$, fresh and dry wt. of nodules $(\mathrm{g})$, grain yield $\left(\mathrm{t} \mathrm{ha}^{-1}\right)$ and fresh biomass $\left(\mathrm{t} \mathrm{ha}^{-1}\right)$ of lentil

\begin{tabular}{|c|c|c|c|c|c|}
\hline $\begin{array}{l}\text { Rate of application of } \mathrm{F} \\
\text { organic fertilizer }\left(\mathrm{kg} \mathrm{ha}^{-1}\right)\end{array}$ & RP-enriched No. of nodules plant ${ }^{-1}$ & $\begin{array}{l}\text { Fresh weight } \\
\text { nodules }^{-1 a n t^{-1}}(\mathrm{~g})\end{array}$ & $\begin{array}{l}\text { of Dry weight of } \\
\text { plant }^{-1}(\mathrm{~g})\end{array}$ & $\begin{array}{l}\text { nodules Grain yield } \\
\left(\mathrm{t} \mathrm{ha}^{-1}\right)\end{array}$ & $\begin{array}{l}\text { Fresh biomass } \\
\left(\mathrm{t} \mathrm{ha}^{-1}\right)\end{array}$ \\
\hline $100 \dagger$ & $26 \mathrm{e}^{*}$ & $2.28 \mathrm{~b}$ & $0.48 \mathrm{~cd}$ & $0.45 \mathrm{e}$ & $2.95 \mathrm{~d}$ \\
\hline 200 & $25.7 \mathrm{e}$ & $2.50 \mathrm{~b}$ & $0.45 \mathrm{~d}$ & $0.55 \mathrm{e}$ & $3.13 \mathrm{~d}$ \\
\hline 400 & $38.0 \mathrm{c}$ & $2.70 \mathrm{~b}$ & $0.47 \mathrm{~d}$ & $0.85 \mathrm{~d}$ & $3.73 \mathrm{bc}$ \\
\hline 500 & $43.3 \mathrm{~b}$ & $2.67 \mathrm{~b}$ & $0.58 \mathrm{a}-\mathrm{c}$ & $1.07 \mathrm{c}$ & $3.73 \mathrm{bc}$ \\
\hline 800 & $44.7 \mathrm{ab}$ & $2.57 \mathrm{~b}$ & $0.59 \mathrm{ab}$ & $1.15 \mathrm{bc}$ & $3.97 \mathrm{~b}$ \\
\hline 1000 & $48.7 \mathrm{a}$ & $3.52 \mathrm{a}$ & $0.64 \mathrm{a}$ & $1.36 \mathrm{a}$ & $4.74 \mathrm{a}$ \\
\hline NPK & $46 \mathrm{ab}$ & $2.77 \mathrm{~b}$ & $0.64 \mathrm{a}$ & $1.28 \mathrm{ab}$ & $4.64 \mathrm{a}$ \\
\hline
\end{tabular}

* Means followed by the same letters are not statistically different at $P<0.05$ according to least significance difference (LSD) test

$\dagger$ Rate of application of RP-enriched organic fertilizer $\left(\mathrm{kg} \mathrm{ha}^{-1}\right)$

Ethylene is produced under abiotic and biotic stress. The process of infection of rhizobia for nodule formation produces ethylene, which causes stress on the plant root growth (van Workum et al., 1995; Suganuma et al., 1995). The ethylene stress might be neutralized by the application of microbial strain with ACC-deaminase activity. Moreover, the P-solubilizing activity of the strain enhanced the availability of $\mathrm{P}$ in the raw $\mathrm{P}$ sources i.e. RP to the crop plants, which ultimately resulted in improved nodulation, growth and yield of lentil. Our results showed that a maximum nodulation with the application of RP-enriched organic fertilizer with impregnation ratio of 50:50 RP and compost, application at the time of seven days before sowing and application rate of $1000 \mathrm{~kg} \mathrm{ha}^{-1}$. This implies that the PSM inoculation had a positive effect on the nodulation through their P-solubilizing and ACC-deaminase activities. Moreover, plant available $\mathrm{P}$ is increased via the production of organic acids and proton extrusion during composting (Surange, 1995) and ethylene stress is reduced through their ACC-deaminase activity (Glick et al., 1998). 
Ditta et al. / Int. J. Agric. Biol., Vol. 17, No. 3, 2015

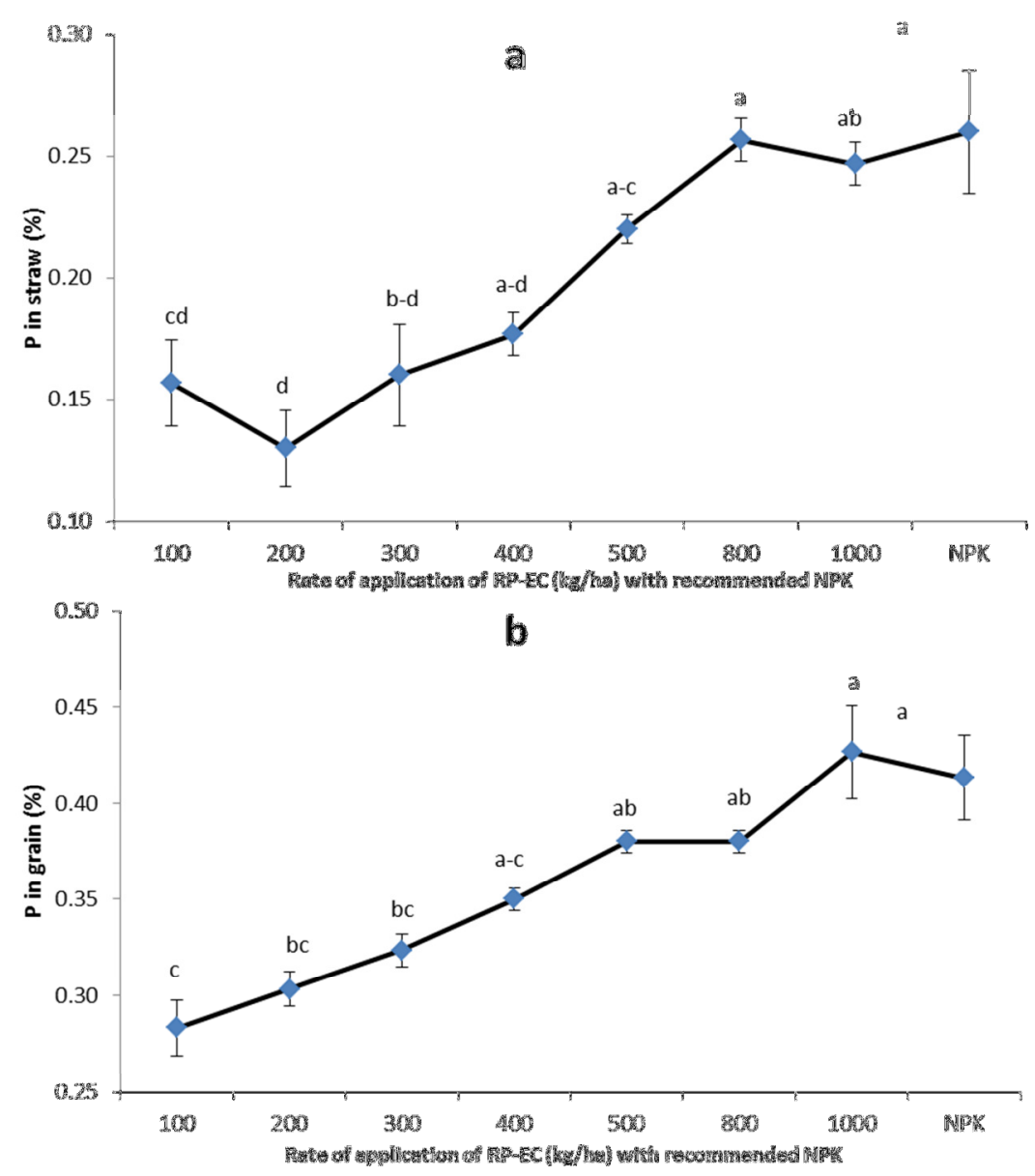

Fig. 1: Impact of rate of application of the optimum ratio and time of rock phosphate impregnation on $P(\%)$ in straw (a) and grain (b). Means followed by the same letters are not statistically different at $P<0.05$ according to least significance difference

The organic material served as a substrate for the microbial population (Verma et al., 2013). Moreover, the compost also served as nutrient source for the microbes as well as for the crop plants (Chang and Janzen, 1996; Paul and Clark, 1996; Nevens and Reheul, 2003). This premise is supported by the increase in $\mathrm{P}$ content of straw and grains of lentil (Table 2 and 3; Fig. 1). Several researchers have found an increase in nodulation in legumes by the inoculation of microbes carrying ACC-deaminase activity (Ma et al., 2004; Shaharoona et al., 2006; Shahzad et al., 2008).

The uptake of $\mathrm{P}$ of lentil was also improved, which might be due to an increased availability of $\mathrm{P}$ through increased solubilization of RP by the application of PSM and through optimum impregnation ratio of RP and compost. Better root growth to explore more soil and to get more nutrients was observed due to the ACC-deaminase activity of the PSM used (Shaharoona et al., 2006; Yang et al., 2009).

In conclusion, combined application of RP-enriched organic fertilizer with optimum impregnation ratio of RP and compost (50:50), time of application (seven days before sowing) and application rate of RP-enriched organic fertilizer@1000 kg ha ${ }^{-1}$ could produce the maximum nodulation, growth and yield parameters of lentil and could provide an economical and sustainable source of $\mathrm{P}$ for sustainable agriculture. The results of the application rate of 800 and $1000 \mathrm{~kg} \mathrm{ha}^{-1}$ were similar so application rate of 800 $\mathrm{kg} \mathrm{ha}{ }^{-1}$ could be recommended on economical basis. However, multi-sites field trials with optimum rate need to be performed to warrant successful performance in the field.

\section{Acknowledgement}

Financial support for this study was provided by the Higher Education Commission of Pakistan, under Indigenous $\mathrm{Ph}$. D. Fellowship Program. We are also thankful to Dr. Khurram S. Baig for giving us bacterial strain (KAP6) used in the study. We are also thankful to Microbiology Section at Ayub Agricultural Research Institute (AARI), Faisalabad for providing rhizobia specific to lentil. 


\section{References}

Akande, M.O., J.A. Adediran, F.I. Oluwatoyinbo, E.A. Makinde and M.T Adetunji, 2008. Suitability of poultry manure amended Sokoto rock phosphate on growth, nutrient uptake and yield of Chilli pepper (Capsicum fruitscens L). Nig. J. Soil Sci., 18: 167-174

Analytical Software, 2005. Statistix 8.1 User's Manual. Analytical Software, Tallahassee, USA

Arshad, M. and W.T. Frakenberger Jr., 2002. Ethylene: Agricultural Sources and Applications. Kluwer/Academic Publishers, New York

Aziz, T., Rahmatullah, M.A. Maqsood, I.A. Tahir and M.A. Cheema, 2006. Phosphorus utilization by six brassica cultivars (Brassica juncea L.) from tri-calcium phosphate; a relatively insoluble $\mathrm{P}$ compound. Pak. J. Bot., 38: 1529-1538

Baig, K.S., M. Arshad, B. Shaharoona, A. Khalid and I. Ahmed, 2012. Comparative effectiveness of Bacillus spp. Possessing either dual or single growth-promoting traits for improving phosphorus uptake, growth and yield of wheat (Triticum aestivum L.). Ann. Microbiol., 62: $1321-1330$

Bangar, K.C., S. Shanker, K.K. Kapoor, K. Kukreja and M.M. Mishra, 1989. Preparation of nitrogen and phosphorus-enriched paddy straw compost and its effect on yield and nutrient uptake by wheat (Tricium aestivum L.). Biol. Fert. Soils, 8: 339-342

Biswas, D. and G. Narayanasamy, 2006. Rock phosphate enriched compost: An approach to improve low-grade Indian rock phosphate Bioresour. Technol., 97: 2243-2251

Caravaca, F., M.M. Alguacil, R. Azcon, G. Diaz and A. Roldan, 2004. Comparing the effectiveness of mycorrhizal inoculum and amendment with sugar beet, rock phosphate and Aspergillus niger to enhance field performance of the leguminous shrub Dorycnium pentaphyllum L. Appl. Soil Ecol., 25: 169-180

Chang, C. and H.H. Janzen, 1996. Long-term fate of nitrogen from annual feedlot manure application. J. Environ. Qual., 25: 785-790

Chen, Y., P. Rekha, A. Arun, F. Shen, W.A. Lai and C. Young, 2006. Phosphate solubilizing bacteria from subtropical soil and their tricalcium phosphate solubilizing abilities. Appl. Soil Ecol., 34: 33-41

Chien, S.H., 1979. Dissolution of phosphate rock in acid soils as influenced by nitrogen and potassium fertilizers. Soil Sci., 127: 371-376

Chien, S.H. and R.G. Menon, 1995. Agronomic evaluation of modified phosphate rock products. IFDC's experience. Fert. Res., 41: 197-209

Condron, L.M., B.L. Turner and B.J. Cade-Menun. 2004. Chemistry and dynamics of organic phosphorus. In: Phosphorus: Agriculture and the Environment. J.T. Sims and A.N. Sharpley (eds.). SSSA Madison, WI, USA

Darzi, M.T., M.H. Seyedhadi and F. Rejali, 2012. Effects of the application of vermicompost and phosphate solubilizing bacterium on the morphological traits and seed yield of anise (Pimpinella anisum L.). J. Med. Plants Res., 6: 215-219

Dey, R., K.K. Pal, D.M. Bhatt and S.M. Chauhan, 2004. Growth promotion and yield enhancement of peanut (Arachis hypogaea L.) by application of plant growth promoting rhizobacteria. Microbiol. Res., 159: 371-394

Diaz, L.F., G.M. Savage, L.L. Eggerth and C.G. Golueke, 1993. Composting and Recycling Municipal Solid Waste. Lewis Publishers, Boca Raton, Florida, USA

Glick, B.R., D.M. Penrose and J. Li, 1998.A model for lowering plant ethylene concentration by plant growth promoting rhizobacteria. $J$. Theor. Biol., 190: 63-68

Iqbal, Z., M. Yaqub, M. Akram and R. Ahmad, 2013. Phosphorus fertigation: A technique for enhancing $\mathrm{P}$ fertilizer efficiency and yield of wheat and maize. Soil Environ., 32: 146-151

Jackson, M.L., 1962. Soil Chemical Analysis. Prentice Hall, New York, USA

Jackson, M.L., 1973. Methods of Chemical Analysis. Prentice Hall of India (Pvt.) Ltd, New Delhi, India

Jansson, M., H. Olsson and K. Pettersson, 1988. Phosphatases; origin, characteristics and function in lakes. Hydrobiologia, 170: 157-175

Ma, W., T.C. Charles and B.R. Glick, 2004. Expression of an exogenous 1aminocyclopropane-1-carboxylate deaminase gene in Sinorhizobium meliloti increases its ability to nodulate alfalfa. Appl. Environ. Microbiol., 70: 5891-5897
Mattoo, A.K. and J.C. Suttle, 1991. The Plant Hormone Ethylene. CRC Press, Inc., Boca Raton, Florida, USA

Meena, M.D. and D.R. Biswas, 2014. Changes in biological properties in soil amended with rock phosphate and waste mica enriched compost using biological amendments and chemical fertilizers under wheatsoybean rotation. J. Plant Nutr. 37: 2050-2073

Nautiyal, C.S., 1999. An efficient microbiological growth medium for screening phosphate solubilizing microorganisms. FEMS Microbiol. Lett., 170: 265-270

Nelson, D.W. and L.E. Sommers, 1996. Total carbon, organic carbon and organic matter. In: Methods of Soil Analysis: Part 3-Chemical Methods, pp: 961-1010. Bigham, J.M. (eds). Soil Sci. Soc. Am. Soc. Agron. Inc. Medison, Wisconson, USA

Nevens, F. and D. Reheul, 2003. The application of vegetable, fruit and garden waste (VFG) compost in addition to cattle slurry in a silage maize monoculture: nitrogen availability and use. Eur. J. Agron., 19: 189-203

Paul, E.A. and F.E. Clark, 1996. Soil Microbiology and Biochemistry Academic Press, San Diego, California, USA

Rashid, M., S. Khalii, N. Ayub, S. Alam and F. Latif. 2004. Organic acids production and phosphate solubilization by phosphate solubilizing microorganisms (PSM) under in vitro conditions. Pak. J. Biol. Sci., 7: 187-196

Reddy, M.S., S. Kumar, K. Babita, M.S. Reddy, 2002. Biosolubilization of poorly soluble rock phosphates by Aspergillus tubingensis and Aspergillus niger. Bioresour. Technol., 84: 187-189

Ryan, J., G. Estefan and A. Rashid. 2001. Soil and Plant Analysis. Laboratory Manual. ICARDA, Aleppo, Syria

Saleem, M.M., M. Arshad and M. Yaseen, 2013. Effectiveness of various approaches to use rock phosphate as a potential source of plan available P for sustainable wheat production. Int. J. Agric. Biol., 15: 223-230

Shaharoona, B., M. Arshad and Z.A. Zahir, 2006. Effect of plant growth promoting rhizobacteria containing ACC-deaminase on maize (Zea mays $\mathrm{L}$.) growth under axenic conditions and on nodulation in mung bean (Vigna radiata L.). Lett. Appl. Microbiol., 42: 155-159

Shahzad, S.M., A. Khalid, M. Arshad, M. Khalid and I. Mehboob, 2008 Integrated use of plant growth promoting bacteria and P-enriched compost for improving growth, yield and nodulation of chickpea. Pak. J. Bot., 40: 1735-1441

Shahzad, S.M., A. Khalid, M.S. Arif, M. Riaz, M. Ashraf, Z. Iqbal and T. Yasmeen, 2014. Co-inoculation integrated with P-enriched compost improved nodulation and growth of Chickpea (Cicer arietinum L.) under irrigated and rainfed farming systems. Biol. Fertil. Soils, 50: 1-12

Steel, R.G.D., J.H. Torrie and D.A. Dicky, 1997. Principles and Procedures of Statistics: A Biometrical Approach, pp: 204-227. McGraw-Hill, Singapore

Suganuma, N., H. Yamauchi and K. Yamamoto, 1995. Enhanced production of ethylene by soybean roots after inoculation with Bradyrhizobium japonicum. Plant Sci., 111: 163-168

Surange, S., A.G. Wollum, N. Kumar and C.S. Nautiyal. 1995. Characterization of Rhizobium from root nodules of leguminous trees growing in alkaline soils. Can. J. Microbiol., 43: 891-894

US Salinity Lab. Staff, 1954. Diagnosis and Improvement of Saline and Alkali Soil, p: 160. USDA Hand book No. 60, US. Govt. Printing Office, Washington DC, USA

van Workum, W.A.T., A.A.N. Van Brussel, T. Tak, C.A. Wijffelman and W.J. Kijne, 1995. Ethylene prevents nodulation of Vicia sativa ssp. nigra by exopolysaccharides deficient mutants of Rhizobium leguminosarum bv viciae. Mol. Plant Microbe Interac., 8: 278-285

Vance, C.P., C. Uhde-Stone and D.L. Allan, 2003. Phosphorus acquisition and use: critical adaptations by plants for securing a nonrenewable resource. New Phytol., 157: 423-447

Verma, S.L., C. Penfold and P. Marschner, 2013. Mobilization of rock phosphate by surface application of compost. Biol. Fertil. Soils, 49: 287-294

Yang, J., J.W. Kloepper and R. Choong-Min, 2009. Rhizosphere bacteria help plants tolerate abiotic stress. Trends Plant Sci., 14: 1-4

(Received 26 November 2014; Accepted 02 December 2014) 